Kristoffersen, A. (2018) Dual læringsmodell i trafikklærerutdanningen Scandinavian Journal of Vocations in development http://dx.doi.org/10.7577/sjvd.3058

Fagfellevurdert artikkel

(Peer reviewed article)

\title{
Dual læringsmodell i trafikklærerutdanningen
}

Forfatter:

Anders Kristoffersen

universitetslektor

OsloMet - storbyuniversitetet

Fakultet for lærerutdanning og internasjonale studier,

Institutt for yrkesfaglærerutdanning

andkr@oslomet.no

Nøkkelord: Trafikklærerutdanning, arbeidsplassbasert læring, effektiv tilegnelse av undervisningskompetanse, effektiv tilegnelse av kjøreferdigheter for elever, erfaring fra det virkelige liv

Keywords: Driving instructor education, workplace learning, efficiency in maintaining teaching skills, efficiency in driving skills for pupils, real life experience 


\section{Abstract}

Since 2012 Oslo and Akershus University College of Applied Sciences (HiOA), now Oslo Met - Oslo Metropolitan University, has been offering a two-year program for driving instructor students. The principle in our dual learning model is that students practice as much as possible in authentic driving schools, and also get their theoretical input at the university each week.

Tron Inglar (2015) claims that teachers need a high level of proficiency to be able to perform their profession with high standards. Stephen Billett (2008) leans on Joseph Raelin and claims that workplace learning experiences offer an effective means for maintaining skill currency across working lives as well as meeting specific enterprise skill needs.

My project seeks to examine how the organization of our learning model might contribute to the education of driving instructors who are well prepared to enter the profession. In order to address this, I have conducted observations of the students' teaching practice, and conducted group interviews with the students and their supervisors.

Findings show that workplace learning at an authentic driving school make the students appear more effective and confident in themselves before they start their careers as driving instructors. The findings also identify how the students provide good learning experiences for the pupils. Some challenges in our learning model were also discovered. 


\section{Sammendrag}

Trafikklærerstudentene følger en læringsmodell der de er to dager ute i praksis og tre dager på universitetet gjennom hele studiet. I denne artikkelen retter jeg oppmerksomheten mot trafikklærerstudentenes læringsutbytte gjennom denne læringsmodellen. Jeg observerte studentenes undervisning i bil og klasserom og gjennomførte fokusgruppeintervjuer av studenter og praksisveiledere i to ulike semestre, for å finne ut hvilke sider av læringsmodellen som bidro til å gjøre studentene godt forberedt til yrket, og hvilke sider som ga større utfordringer enn ønsket. Meningsinnholdet i kyndighetsbegrepet sto sentralt i undersøkelsen (Inglar, 2015)

Problemstillingen er: På hvilken måte kan en læringsmodell som i hovedsak har lik fordeling mellom læring i klasserommet og læring på arbeidsplassen framskaffe trafikklærere som er godt forberedt på yrkeslivet?

Undersøkelsen viste blant annet at når studentene fikk undervise reelle kjøreelever ved reelle trafikkskoler, fikk de et godt innblikk i hverdagen til yrkesutøverne, samtidig som de fikk god undervisningserfaring med kjøreelever med ulike forutsetninger, og erfaring med mange ulike trafikale utfordringer. På den annen side sto ofte den økonomiske faktor i veien for en tett og god oppfølging av studentene, fordi praksisveilederne i en del tilfeller var mer fokusert på å gjennomføre egne undervisningstimer framfor å følge opp studentene. Mange små enheter medførte i tillegg noen ulikheter i kvaliteten på oppfølgingen av studentene, og avstanden mellom teori- og praksisfeltet kunne også være en utfordring.

Hensikten med undersøkelsen var å rette oppmerksomheten mot utfordrende faktorer ved vår duale læringsmodell. Dette vil deretter legge grunnlaget for videre utvikling av trafikklærerstudiet i den hensikt å gjøre kvaliteten på studiet enda bedre. 


\section{Introduksjon}

Helt siden norsk trafikklærerutdanning ble formalisert på begynnelsen av 1970-tallet har utdanningen vekslet ukentlig mellom teori og praksis (Torsmyr, 2007). Det er en betydelig forenkling å benytte begrepene «teori» og «praksis» om de ulike læringsaktivitetene på universitetet og ved praksisskolene, men jeg har likevel valgt å la de representere aktivitetene i læringsmodellen vi benytter på trafikklærerutdanningen ved OsloMet - Storbyuniversitetet.

Hovedprinsippet bak vår læringsmodell er at studentene skal ha så mye praksis som mulig. Denne baserer seg på at læring på arbeidsplassen er et effektivt middel for å tilegne seg ferdigheter i arbeidslivet og dermed møte trafikkskolenes spesifikke ferdighetsbehov (Billett, 2008; Boud \& Solomon, 2001). Studentene er tre dager i uka på universitetet, og to dager ved en trafikkskole (praksisskole), der de underviser kjøreelever under veiledning av utvalgte praksisveiledere. Praksisveilederne må gjennomføre et veiledningsstudium på minst 30 studiepoeng før de kan veilede for studentene.

Konfluent pedagogikk er framtredende i trafikklærerstudiet. Den motoriske, kognitive og affektive dimensjon flyter sammen til en helhet (Grendstad, 1956), og danner grunnlaget for studentenes og trafikklærernes pedagogiske og didaktiske tilrettelegging. Gjennom helheten i en konfluent tilnærming bør kyndighet skapes både hos studentene og hos kjøreelevene. Begrepet «kyndighet» har derfor stått sentralt i min unders $\emptyset$ kelse (Inglar, 2015). Læreplanen for førerkortklasse B, B96 og BE sier at undervisningen skal tilrettelegges med utgangspunkt i den enkelte elevs behov (Statens vegvesen, 2016, s.16), og at utvikling av selvinnsikt er viktig for å skape trafikksikre bilførere (Statens vegvesen, 2016, s.14). Å basere undervisningen på konfluente prinsipper er dermed viktig for å oppfylle læreplanens mål.

For å se nærmere på i hvilken grad vår duale læringsmodell lykkes med å skape kyndige studenter og kjøreelever gjennomførte jeg en empirisk undersøkelse i perioden 2014 til 2016, der jeg blant annet intervjuet studenter og praksisveiledere. I tillegg gjennomførte jeg to runder med observasjon av undervisning i bil og klasserom, der jeg så etter kjennetegn på kyndighet i undervisningen, samt effekten av mye studietid ute i praksis. Veksling mellom teori og praksis, konfluent tilnærming og kyndighet er altså sentrale i trafikklærerutdanningen, og har dermed også stått sentralt i undersøkelsen.

Undersøkelsen ga blant annet indikasjoner på at studentene blir flinke til å håndtere ulike elevtyper, at studenter som er svake teoretisk, også viser svakheter i undervisningen. Men undersøkelsen ga også indikasjoner på at studenter som framstår som sterke innenfor 
teorifeltet, lett kan «falle gjennom» $\mathrm{i}$ undervisningen når de føler seg for «flinke» til å planlegge timene grundig nok. Unders $\emptyset$ kelsen avdekket også læringsmodellens sårbarhet. Ulike praksisskoler med ulikt ståsted og ulik tilgang på ressurser, medfører at studenter ofte merker til dels store ulikheter i oppfølging fra praksisveileder, og i tilgang på kjøreelever.

\section{Dual læringsmodell og kyndighetsutvikling}

En utdanning som bidrar til å framskaffe kritiske og selvstendig tenkende trafikklærere som gjennom sin praktisk rettede utdanning har opparbeidet sin egen praksisteori som grunnlag for sin undervisning, vil bidra til å ta både yrket og kjøreelevene på alvor. De har ofte egne standpunkt framfor å påvirkes av andre. Hvis ikke den kunnskapen som studentene får i trafikklærerutdanningen blir praksistilknyttet og personlig, kan de lettere fanges opp av handlingsmønstre i den lokale skolekulturen (Hiim \& Hippe, 2011). Trafikkopplæringsmiljøet består av mange mindre trafikkskoler som har lett for å utvikle sin egen skolekultur. I de fleste tilfeller er denne bygget på Trafikkopplæringsforskriftens intensjoner, men i noen tilfeller har kulturen utviklet seg mer i retning av trafikkskolens egne ønsker og oppfatninger. Studenter og framtidige yrkesutøvere som er i stand til å oppdage dette, vil være en ressurs for trafikkopplæringsmiljøet.

Ett av målene med mye praksis i trafikklærerutdanningen er å utvikle studentenes praktiske kyndighet. Tron Inglar benytter begrepet «kyndighet» om både teoretiske kunnskaper og praktiske ferdigheter, framfor begrepet «kunnskap», som ofte er knyttet til det kognitive området. (Inglar, 2015). I Læreplan for førerkortklasse B, B kode 96 og BE (heretter kalt «læreplanen») finner vi begrepene «førerkompetanse» og «trafikal ferdighet». Førerkompetanse omfatter både kunnskaper, ferdigheter, holdninger og motivasjon som føreren trenger for å mestre trafikkmiljøet på en sikker måte. Trafikal ferdighet omfatter både kunnskap om lover og regler og god kjøreteknisk ferdighet. God kjøreteknisk ferdighet behøves for å slippe å konsentrere seg om giring, bremsing og styring under den trafikale treningen. De erfaringene kjøretreningen gir, er viktige for at eleven skal få innsikt i egne handlinger og vurderinger (Statens vegvesen, 2016, s. 13).

Å utvikle «praktisk klokskap» hos kjøreeleven er viktig for å oppnå et sikkert trafikkmiljø. Både Platon og Aristoteles viser hvordan det å utvikle praktisk klokskap (phronesis) handler om å gå inn i en situasjon med en intensjon om å gjøre noe på en best mulig måte og i etterkant reflektere over situasjonen (Eikeland, 2008; Kversøy, 2015). På den måten kan man ta konsekvensen av det man oppdager med seg slik at man kan handle annerledes i fremtiden. «For både Platon og Aristoteles er dette et samspill mellom hode 
(tanker), hjerte (følelser) og hender (handling). Vår refleksjon må ta hensyn til disse ulike domenene» (Kversøy 2015, s. 84).

Når vi vet hva det står om førerkompetanse og trafikal ferdighet i læreplanen, er det interessant at Inglar knytter utvikling av kyndighet til nettopp bilkjøring. Kyndighet må opparbeides av både trafikklæreren og kjøreeleven. Å utøve praktisk klokskap på veien mot å bli en god trafikklærer eller en trygg trafikant står sentralt i trafikkopplæringen og i trafikklærerutdanningen. Tron Inglar sier videre at vi kun husker et utvalg av det som skjer rundt oss, og at vi noen ganger kan komme opp i situasjoner der vi ikke har noen erfaringer å handle ut fra, mens vi andre ganger kommer opp i situasjoner der vi utfører handlingene på grunnlag av tanker eller intensjoner, noe han betegner som «teoretisk kyndighet», eller på grunnlag av skjønn, eller med andre ord «praktisk kyndighet». «Når vi handler ut fra en spesifikk intensjon, er handlingene basert på læring. Dette forutsetter igjen at opplevelsene er videre bearbeidet til erfaringer, eller at vi har kunnskaper som gjør at vi handler på en bestemt måte» (Inglar, 2015, s. 22-23). Dette betyr at både studenter og kjøreelever behøver mye praksis for å opparbeide den kompetansen som kreves. Studentene opparbeider seg forhåpentligvis denne gjennom mye praksis og bearbeidelse av erfaringene fra praksis, mens intensjonen i trafikkopplæringen er at kjøreelevene skal opparbeide seg denne gjennom en god og tilpasset tilrettelegging fra trafikklæreren (Statens vegvesen, 2006, s. 10-17).

Å lære å kjøre bil, og å lære å bli en god trafikklærer, forutsetter altså i stor grad at opplevelser er videre bearbeidet til erfaringer, og at erfaringene danner grunnlaget for handlingsvalg som gjøres. John Dewey mente at erfaringer er en spesiell kombinasjon av eksperimenterende handlinger og de konsekvensene handlingene fører med seg (Inglar, 2015, s. 23). Dewey med sin «instrumentalisme» hevder også at tenkningen er et instrument eller et redskap for handling, og at kunnskap skapes gjennom å utføre handlinger for deretter å reflektere og lære («experiential learning») gjennom handlingen for å finne svar på hva som kunne vært gjort annerledes. Fellesskap og medvirkning i klasserommet er viktig. Gjennom å gjøre relevante aktiviteter sammen utvikler vi felles erfaringer og felles språk (Dewey, 1916/1985; Dewey, 1938/2008). For kjøreeleven er trafikkmiljøet klasserommet. Når kjøreeleven har gjort en feil, vil trafikkmiljøet feilen ble begått i, være endret i løpet av sekunder. Fellesskapet endres, og alle aktørene i situasjonen må medvirke til å finne løsninger basert på felles erfaring og felles trafikalt språk. Læreren kan ta eleven tilbake til stedet der feilen ble gjort, men i mange tilfeller vil trafikksituasjonen på samme sted ikke være den samme som da feilen ble begått. Noen lærere benytter video, noe som kan være et greit 
redskap for å gjenoppleve den aktuelle situasjonen, men eleven får likevel ikke fullt og helt opplevd en identisk situasjon på nytt. Ved å kjøre gjennom liknende situasjoner en rekke ganger for å gi eleven et solid erfaringsgrunnlag, bidrar til å utvikle praktisk kyndighet og klokskap. Da er elevens intensjonelle handlinger basert på læring, og opplevelsene videre bearbeidet til erfaringer. Inglar knytter praktisk kyndighet til begrepene sansing, ferdigheter, håndlag, kroppsbeherskelse, minner om opplevelser, visuelle minner, utøvelse av skjønn, bruk av redskaper og instrumenter, og vurdering av når noe er godt nok. På samme måte som en kjøreelev må opparbeide praktisk kyndighet for å kunne beherske kjøretøyet og trafikkbildet, må trafikklærerstudentene opparbeide praktisk kyndighet for å kunne undervise kjøreelevene i et skiftende trafikkmiljø (Inglar, 2015).

På denne bakgrunnen kom jeg fram til følgende problemstilling: På hvilken måte kan en læringsmodell som i hovedsak har lik fordeling mellom læring i klasserommet og læring på arbeidsplassen framskaffe trafikklærere som er godt forberedt på yrkeslivet?

\section{Kyndighetstrekk i trafikklærerutdanningen}

Sansingen foregår først og fremst gjennom observasjon av medstudenter og kjøreelever. Hver uke underviser og observerer studentene både elever og hverandre. Minst to studenter må arbeide sammen i samme bil eller klasserom; en student underviser og en (eller flere) studenter observerer fra baksetet og gir tilbakemelding på undervisningen i etterkant av timen. Dette gjør at studentene har mulighet til å opparbeide seg praksiserfaring lenge før de skal ut å praktisere yrket på egen hånd. For en kjøreelev er «kjøreprosessen» viktig å være bevisst på. Første ledd er å sanse. Hele prosessen, som pågår kontinuerlig, er å sanse oppfatte - avgjøre - handle. Handlingene avgjøres primært av hva som sanses, oppfattes og avgjøres i forhold til ulike trafikksituasjoner, basert på det erfaringsgrunnlaget kjøreeleven har opparbeidet seg. Dette betyr altså at kyndighetstrekket å sanse foregår på både studentnivå og elevnivå.

Ferdigheter er en viktig del av å kjøre bil. «Førerkompetanse kan altså sees på som de kunnskaper, ferdigheter, holdninger og den motivasjon føreren trenger for å mestre trafikkmiljøet på en sikker måte» står det i læreplanen (Statens vegvesen, 2016, s. 10). Ferdigheter er altså bare ett aspekt ved den førerkompetansen som trafikklæreren skal framdyrke hos kjøreelevene. Det står videre at

... føreren må ha ferdigheter i å tolke de ulike trafikksituasjoner, og vurdere hvilken atferd som er passende. Det kreves også at føreren kan leve seg inn i andres situasjon; føreren må ha 
empati. Samtidig må føreren ha tilstrekkelig selvkontroll til å handle i tråd med egne vurderinger basert på hensiktsmessighet og sikkerhet (Statens vegvesen, 2016, s. 10).

Trafikklæreren må altså ha et ferdighetsnivå som ligger langt over det som kreves av elevene. En viktig faktor for å opparbeide dette hos trafikklærerstudenten, er kombinasjonen mellom teori og praksis, der studenten først er i ute praksis, og deretter kommer tilbake til klasserommet for teoriutdypning og refleksjon, før ny utprøving skjer ute i praksis. Ferdighetsbegrepet deles i to i læreplanen: «Kjøreteknisk ferdighet» som blant annet betyr at sjåføren må ha gode, automatiserte ferdigheter, og dermed slippe å konsentrere seg om giringen, bremsingen og styringen, men heller om andre trafikanter under kjøring, og «trafikal ferdighet» som blant annet betyr at kjøreeleven skal lære seg å samhandle på en trafikksikker måte med andre trafikanter.

Håndlag utvikles i hovedsak gjennom studentenes regelmessige praksis. Trafikklærerstudentene arbeider med både undervisning, observasjon, refleksjon og tilbakemelding fra praksisveileder, medstudenter og faglærer når de er ute i praksis. Gjennom mine observasjoner kan jeg se at de fleste studentene ikke bare har utviklet håndlaget som trengs i undervisningen av kjøreelevene, men også håndlaget som trengs for å beherske alle sider ved trafikklæreryrket, når de nærmer seg slutten av studiet. Dette kan være alt fra å skaffe nye elever, ta telefonen på kontoret, holde orden på undervisningstimer og undervisningsprogresjon for den enkelte elev, til vaske skolebilen.

Kroppsbeherskelse, som innenfor trafikk og bilkjøring beskrives som «kontroll over egne plutselige innskytelser, aggresjon og andre forstyrrende emosjoner» er en viktig side av den trafikale kompetansen som kjøreelevene skal opparbeide seg (Statens vegvesen, 2016, s. 10). Trafikklæreren må vite hvordan dette kan gjøres både med «normalelever» og elever med spesielle behov. Studentene ved en av våre praksisskoler har undervist elever som har vært en del av et ungdomsprosjekt, og har fått mange utfordringer og erfaringer med å undervise elever som trenger spesiell tilrettelegging.

En viktig side ved trafikkopplæringen er å gi kjøreelevene så mange minner om opplevelser og visuelle minner som mulig. Trafikklæreren må arbeide for at eleven skal få tilstrekkelig antall timer slik at opplæringen gir best mulig resultat, samtidig som hensynet til $\emptyset$ konomi og effektivitet må være i fokus. Det viser seg at kjøreelever som gjennomfører hele eller deler av sin opplæring med en student, ofte får flere kjøretimer enn elever som er fullbetalende kunder. Studentene må også kjenne til kravene om et godt og nært samarbeid 
med kjøreelevenes foreldre eller andre som kan være ledsagere under privat øvingskjøring, siden denne siden ved trafikkopplæringen er ønskelig for å gi kjøreeleven så mye erfaring som mulig i opplæringen.

I vår læringsmodell forventes det at trafikklærerstudentene utvikler evne til utøvelse av skjønn. For å kunne utøve skjønn, må man ha mye praksiserfaring slik at man kan stå på egne ben og ta egne valg. Man må ha evnen til å se og oppdage ulikheter mellom elever, og i tillegg oppdage elevens sterke og svake sider. Men evne til utøvelse av skjønn skal også utvikles hos kjøreeleven. Dette foregår gjennom en trafikkopplæringsmodell som består av et «trekantsamarbeid» mellom trafikklærer, kjøreelev og ledsager, og en trafikklærer som klarer å overføre denne egenskapen fra seg selv til eleven. Når kjøreleven får god oppfølging av trafikklæreren vil eleven kunne utvikle evne til å utøve skjønn bygget på erfaring i ulike trafikksituasjoner. Jo mer erfaring en elev får i opplæringen, jo mer trafikksikker vil eleven kunne bli som sjåfør på egen hånd.

Bruk av redskaper og instrumenter hører innunder den kjøretekniske ferdigheten som er omtalt i læreplanen blant annet som «å ha gode, automatiserte kjøretekniske ferdigheter» (Statens vegvesen, 2016, s. 13). En bil kan lett oppfattes som et komplekst og uhåndterlig redskap hvis ikke god opplæring har funnet sted og automatisering har vært resultatet av dette.

Vurdering av når noe er godt nok synes en del av trafikklærerstudentene er en utfordring. De sier at det er problematisk å vite når «nok er nok» og om en bør gå videre til nye temaer. Mange har imidlertid erfart at temaene stadig kommer opp igjen og at det uansett har foregått tilstrekkelig undervisning og erfaringslæring underveis i opplæringen og at temaer som studenten mener er underfokusert, kun er en følelse av usikkerhet en student ofte vil ha.

\section{Metode}

Tidligere forskning peker på at mye praksis i utdanningen bidrar til å framskaffe framtidige yrkesutøvere som er godt forberedt og har god kjennskap til yrkets mangfold og utfordringer, men også at spenningsfeltet mellom teori og praksis har en del utfordringer (Billett, 2008; Haaland, 2015; Hiim \& Hippe, 2009, 2011; Inglar, 2009, 2015). I undersøkelsen ville jeg, i tillegg til å finne ut mer om kyndighetsutviklingen hos studenter og elever, se nærmere på hvor utfordringene i trafikklærerstudiet ligger, og hva som eventuelt kan endres. Under observasjonene ute i bil og i klasserom skrev jeg både feltnotater underveis og fylte ut observasjonsskjemaer i etterkant. Semistrukturerte fokusgruppeintervjuer med 
praksisveiledere og studenter ble gjennomført ved hjelp av intervjuguider som inneholdt et sett med basisspørsmål. Men intervjuene ble i stor grad også tilpasset intervjupersonenes svar.

For å få et best mulig inntrykk av studentenes kyndighetsutvikling, observerte jeg studentenes undervisning på to ulike stadier; en observasjonsrunde i tredje semester, og en i fjerde semester. Dette foregikk mens studentene underviste ulike kjøreelever på ulikt nivå i trafikkopplæringen.

Observasjonene ble gjennomført høstsemesteret 2015 og vårsemesteret 2016. Hvert av fokusgruppeintervjuene med studentene hadde åtte deltakere i hver gruppe, og fokusgruppeintervjuet med praksisveilederne hadde også åtte deltakere.

\begin{tabular}{|l|l|}
\hline TIDSROM & TILTAK \\
\hline $\begin{array}{l}\text { Høstsemesteret 2015 (19.08.-17.12.) } \\
\text { 3. semester }\end{array}$ & $\begin{array}{l}\text { Observasjon i bil. Student underviser. } \\
\text { Feltnotater. Observasjonsskjema. 22 } \\
\text { observasjoner }\end{array}$ \\
\hline $\begin{array}{l}\text { Vårsemesteret 2016 (20.01.-06.04.) } \\
\text { 4. semester }\end{array}$ & $\begin{array}{l}\text { Observasjon i bil. Student underviser. } \\
\text { Feltnotater. Observasjonsskjema. } 13 \\
\text { observasjoner }\end{array}$ \\
\hline Vårsemesteret 2016(04.04.) & $\begin{array}{l}\text { Intervju med 8 studenter i 2 ulike grupper. } \\
\text { 46 og 42 minutter }\end{array}$ \\
\hline Vårsemesteret 2016 (09.05.) & Intervju med 8 praksisveiledere. 33 minutter \\
\hline Vårsemesteret 2016 (15.06.) & Emneevaluering. Utvalgte spørsmål benyttes \\
\hline
\end{tabular}

Tabell 1. Oversikt over empiriinnhentingen

Observasjonene i bil foregikk ved at jeg satt i baksetet uten å kommentere noe. Noen ganger var praksisveileder med i bilen, noen ganger en medstudent. Plassforholdene i skolebilene gjorde de ikke mulig for både medstudent og praksisveileder å være med samtidig. Observasjonene i klasserom foregikk ved at jeg satt sammen med elevene og tok feltnotater. Etter endt time gjennomførte vi etterveiledning. I tillegg fikk studenten et utfylt vurderingsskjema. Dette skjemaet ble benyttet både til å skrive feltnotatene i mer ordnede former, og til å gi studentene en tilbakemelding på timen. Dette gjorde det mulig å samle inn empiri, samt å veilede studenten og i enkelte tilfeller praksisveilederen.

Intervjuene ble gjennomført i studentenes faste klasserom etter endt undervisning. Tidspunkt på dagen og stemningen etter undervisningen kan ha påvirket svarene. Diktafon ble benyttet under intervjuene. Praksisveilederne ble også intervjuet i det samme klasserommet. 
Dette foregikk kort tid etter at et av våre samarbeidsmøter var gjennomført. Praksisveilederne kan ha vært noe preget av stemningen på dette møtet, noe som kan ha påvirket svarene.

Så ble intervjuene transkribert. Tekstene fra både feltnotatene og de transkriberte intervjuene ble deretter skrevet ut. Meningsinnholdet i både feltnotatene og i intervjuene ble analysert ved hjelp av meningsfortetting. Meningsfortetting er en forkortelse av betydningene av en intervjupersons utsagn til kortere formuleringer (Kvale \& Brinkmann, 2009, s. 324), og har til hensikt å beskrive mennesker og deres erfaringer med, og forståelse av, et fenomen (Johannessen m.fl., 2004, s. 76). Kodene ble klassifisert til ni kategorier: Elevens behov, lærerens behov, endringsatferd, verktøy, lærer-elev, mål, konfluent, begreper og forhold i skjæringspunktet teori-praksis. Deretter foretok jeg selektiv koding av de ni kategoriene (Postholm, 2011, s. 90), og fikk fram kjernekategorien «praksiskompetanse/kyndighet», som representerer unders $\varnothing$ kelsens hovedtema. Fem hovedkategorier kom også fram etter en sammenslåing av enkelte kategorier med en del fellestrekk (Grønmo, 2010, s. 248-249). Mer om dette i kapittelet om resultatene fra undersøkelsen.

\section{Metodens anvendbarhet med tanke på validitet og reliabilitet}

Når validitet handler om hvor godt jeg måler det jeg vil undersøke (Postholm, 2011, s. 170), vil det være på sin plass å komme med noen refleksjoner blant annet rundt eventuelle feilkilder (Kvale \& Brinkmann, 2009, s. 254). Jeg mener i utgangspunktet at stilltiende observasjon av studentenes undervisning av kjøreelever er den beste måten å være «flue på veggen» på, for på best mulig måte finne valide svar på det undersøkelsen krever. Fra bakerst i klasserommet og i baksetet på skolebilene vil jeg kunne observere alt som foregår i studentenes undervisning. Dette vil også bidra til å gi metoden troverdighet (begrepet «troverdighet» benyttes i stedet for «reliabilitet», fordi metodene i kvalitative studier ikke lar seg måle med samme standardiserte opplegg som kvantitative studier (Grønmo, 2010, s. 228-

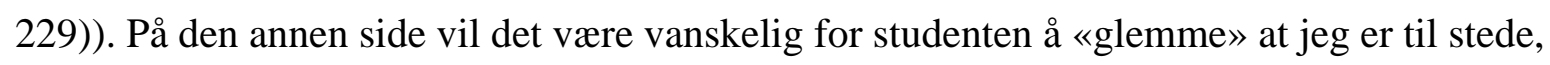
spesielt i klasserommet. Når jeg sitter i baksetet i bilen, uten å gi lyd av noe slag, vil det være et håp om at studenten glemmer meg i kortere eller lengre perioder. Uansett vil en mulig feilkilde være at studenten underviser på en annen måte når jeg er til stede enn om jeg ikke hadde vært i klasserommet eller i bilen.

Også intervjuene ble gjennomført med fokus på så høy validitet og troverdighet som mulig. I stedet for å intervjue én og én student eller praksisveileder, ble disse intervjuet i grupper. Dette var et bevisst valg tatt med utgangspunkt i det asymmetriske forholdet som oppstår, spesielt mellom meg som lærer, og studentene, men også mellom meg og 
praksisveilederne. Å innta en lyttende rolle var viktig for å gi rom for så mye utfoldelse som mulig hos intervjupersonene. Likevel vil dette kunne være en feilkilde i unders $\varnothing$ kelsen, ved at intervjusvarene er preget av en tanke om «å svare det jeg tror at læreren ønsker å høre». Det er likevel en viss sannsynlighet for at både studenter og praksisveiledere ville gitt andre svar på intervjuspørsmålene dersom en annen forsker hadde gjennomført intervjuene, eller at studentene hadde undervist på en annen måte dersom andre enn meg hadde gjennomført observasjonene. Det samme gjelder transkripsjonene. Siden jeg er preget av mitt engasjement innenfor trafikklærerstudiet, kunne blant annet kategoriseringen av intervjupersonenes svar blitt en annen (Kvale \& Brinkmann, 2009, s. 250). Likevel er det viktig å fokusere på fordelene ved å forske på egen praksis. Jeg kjenner alle sidene ved studiet, og ser sider ved observasjonene og intervjusvarene som andre ikke ser. Men det er viktig å være bevisst på alle mulige feilkilder når forskeren har nær tilknytning til forskningsfeltet. Det vil alltid være en risiko ved å forske på egen praksis ((Ulvik, Riese \& Roness, 2016), men å ta de nødvendige forholdsregler ut fra en klar bevissthet om dette, vil kunne opprettholde validiteten i undersøkelsen.

De empiriske resultatene som presenteres i neste kapittel, er uansett basert på data om faktiske forhold i bil og klasserom, og bygger ikke på skjønn eller tilfeldige omstendigheter i forskningsprosessen. Skjema for hva jeg skulle legge vekt på under observasjonsrundene, og intervjuguider med en basiskjerne innenfor prosjektets tema, lå til grunn for innsamlingen av data (Grønmo, 2010, s. 229).

\section{Etiske betraktninger}

Før prosjektet ble igangsatt, gikk jeg gjennom spørsmålene NSD stiller for å finne ut om et prosjekt må meldes inn med tanke på personvern. Det viste seg å ikke være nødvendig på bakgrunn av anonymiseringen i undersøkelsen og i artikkelen. Likevel er det noen etiske betraktninger som bør gjøres.

Før studentene og praksisveilederne ble involvert, ble de informert om hva prosjektet gikk ut på, og hva deres deltakelse ville innebære for dem. Denne informasjonen ble gitt i et samtykkeskjema som ble laget etter en mal fra NSD.

Å forske på egen og egne studenters praksis og å ta utgangspunkt i både sine egne og studentenes erfaringer, gjør at man er svært nær forskningsfeltet og dermed i en del tilfeller mangler nødvendig distanse. Å samle inn data fra egen studentgruppe kan gjøre at jeg stiller meg i en sårbar posisjon, og at studentene også blir sårbare. Å samle inn data i liten skala gjør 
at enkeltpersoner kan bli synlige og i tillegg kan få stor innflytelse på resultatet. Dette gjør at man må tenke seg godt om både i analysen og rundt hva som blir utfallet. Det er viktig at perspektivet er å bruke informasjonen man får inn til å utvikle praksis, og kun det (Ulvik, Riese \& Roness, 2016, s.74-75).

Kvalitativ forskning innebærer å forske på menneskelige prosesser eller problemer i deres naturlige kontekst. I tillegg til det nære forholdet mellom forsker og deltakere som er beskrevet over, er det viktig å avklare min rolle som forsker. På grunn av et noe asymmetrisk forhold mellom lærer og studenter valgte jeg stilltiende observasjon i bil, og å innta en lyttende rolle under gruppeintervjuene. Dette ble gjort for å gi studentene så stor frihet som mulig under de rådende forholdene. Likevel er det nok slik at min rolle som lærer vil styre studentene i en viss grad; de vil ikke være fullt og helt i sin naturlige kontekst med meg til stede (Postholm, 2011).

Jeg har tidligere nevnt at det er viktig å utvikle praktisk klokskap hos trafikklærerstudenten. I undersøkelsen jeg har gjennomført har det også vært viktig for meg å utvise praktisk klokskap når det gjelder etisk tilnærming. Dette baserer seg på Aristoteles`dydsetikk, som i hovedsak går ut på å gjøre oss til gode mennesker ut fra et praktisk formål. Det gjelder altså «å ha evnen til å vurdere og handle i overensstemmelse med bestemte situasjoner på en måte som bidrar til generelt god livsførsel» (Lovibond, 1995, s. 101), framfor å følge universelle etiske prosedyrer. Det har altså vært viktig for meg å ha til hensikt å forbedre den menneskelige situasjonen som har blitt utforsket, og ikke bare diskutere formålet med undersøkelsen med hensyn til vitenskapelig verdi (Kvale \& Brinkmann, 2009, s. 80-85).

\section{Resultater}

Resultatene fra undersøkelsen blir presentert samlet for observasjonene, intervjuene og emneevalueringen. I analysen av datamaterialet kom det fram tre hovedtemaer som ble utledet av fem hovedkategorier og den todelte kjernekategorien. De tre hovedtemaene er utgangspunkt for drøfting av resultatene. Tabellen under viser hovedkategoriene og kjernekategorien. 


\section{Kategorier i analysen}

Feltnotatene 1. runde

\begin{tabular}{|c|c|c|c|}
\hline $\begin{array}{l}\text { Kjerne } \\
\text { kate } \\
\text { gori }\end{array}$ & \multicolumn{3}{|c|}{ PRAKSISKOMPETANSE / KYNDIGHET } \\
\hline $\begin{array}{l}\text { Hoved } \\
\text { kate } \\
\text { gori }\end{array}$ & $\begin{array}{l}\text { HANDLINGSKOMPETANSE } \\
\text { (PRAKTISK KOMPETANSE) }\end{array}$ & KOMMUNIKASJON & $\begin{array}{c}\text { REFLEKSION } \\
\text { (TEORETISK KOMPETANSE) }\end{array}$ \\
\hline
\end{tabular}

Feltnotatene 2. runde

\begin{tabular}{|c|c|c|c|}
\hline $\begin{array}{l}\text { Kjerne } \\
\text { kate } \\
\text { gori }\end{array}$ & \multicolumn{3}{|c|}{ PRAKSISKOMPETANSE / KYNDIGHET } \\
\hline $\begin{array}{l}\text { Hoved } \\
\text { kate } \\
\text { gori }\end{array}$ & $\begin{array}{l}\text { HANDLINGSKOMPETANSE } \\
\text { (PRAKTISK KOMPETANSE) }\end{array}$ & KOMMUNIKASJON & $\begin{array}{c}\text { REFLEKSJON } \\
\text { (TEORETISK KOMPETANSE) }\end{array}$ \\
\hline
\end{tabular}

Observasjonsskjemaene 1. runde

\begin{tabular}{|c|c|c|c|}
\hline $\begin{array}{l}\text { Kjerne } \\
\text { kate } \\
\text { gori }\end{array}$ & \multicolumn{3}{|c|}{ PRAKSISKOMPETANSE / KYNDIGHET } \\
\hline $\begin{array}{l}\text { Hoved } \\
\text { kate } \\
\text { gori }\end{array}$ & $\begin{array}{l}\text { HANDLINGSKOMPETANSE } \\
\text { (PRAKTISK KOMPETANSE) }\end{array}$ & KOMMUNIKASJON & $\begin{array}{c}\text { REFLEKSJON } \\
\text { (TEORETISK KOMPETANSE) }\end{array}$ \\
\hline
\end{tabular}

Observasjonsskjemaene 2. runde

\begin{tabular}{|c|c|c|c|}
\hline $\begin{array}{l}\text { Kjerne } \\
\text { kate } \\
\text { gori }\end{array}$ & \multicolumn{3}{|c|}{ PRAKSISKOMPETANSE / KYNDIGHET } \\
\hline $\begin{array}{l}\text { Hoved } \\
\text { kate } \\
\text { gori }\end{array}$ & $\begin{array}{l}\text { HANDLINGSKOMPETANSE } \\
\text { (PRAKTISK KOMPETANSE) }\end{array}$ & KOMMUNIKASJON & $\begin{array}{c}\text { REFLEKSJON } \\
\text { (TEORETISK KOMPETANSE) }\end{array}$ \\
\hline
\end{tabular}

Intervjuene (alle rundene)

\begin{tabular}{|c|c|c|c|}
\hline $\begin{array}{l}\text { Kjerne } \\
\text { kate } \\
\text { gori }\end{array}$ & \multicolumn{3}{|c|}{ PRAKSISKOMPETANSE / KYNDIGHET } \\
\hline $\begin{array}{l}\text { Hoved } \\
\text { kate } \\
\text { gori }\end{array}$ & UNDERVISNINGSFERDIGHETER & HANDLINGSKOMPETANSE & PRAKSISTILPASNING \\
\hline
\end{tabular}

\section{Tabell 2. Oversikt over kategorier}

Meningsinnholdet i kyndighetsbegrepet (Inglar, 2015, s. 20) var mitt hovedfokus under observasjonene og intervjuene og gjorde at jeg hele veien lette etter kjennetegn på kyndighet i det studenter og praksisveiledere sa og gjorde.

Handlingskompetanse (praktisk kompetanse) kommer fram ved at studenten for eksempel tar hensyn til elevens behov, ved å vise tilstedeværelse i undervisningssituasjonen (ikke snakke i mobiltelefon eller gjøre forefallende arbeid med elev i bilen), eller å være tålmodig med elevens utfordringer. Håndtering av forskjellige elevers ulike behov samt 
håndtering av begreper er i trafikal sammenheng å betrakte som kjennetegn på kyndighet hos studenten. Feltnotatene fra en av observasjonsrundene sier dette: «Studenten kommuniserer bra med eleven, og lar eleven prøve mye selv. Studenten gir positive tilbakemeldinger hver gang eleven gjør noe bra, og stiller gode veiledningsspørsmål når det oppstår noe som eleven må endre på.»

Riktig kommunikasjon med kjøreelevene er en viktig faktor for å skape en god undervisningssituasjon. Under en praksisoppfølging observerte jeg en student som mumlet i et høyt tempo både under kjøring og under ulike refleksjonsstopp i løpet av undervisningstimen. Eleven var på begynnernivå, og i tillegg behersket hun norskspråket dårlig. Hun fikk også kritikk for å ikke mestre de seks ulike temaene hun fikk som øvingsoppgaver. Heldigvis er det flest eksempler på studenter som kommuniserer godt med elevene, og som har overskudd til å bruke humor og å skape en god atmosfære i bilen. Kommunikasjon handler også om kroppens språk på flere plan. Studenter som både ser på eleven og peker for å vise forskjellige ting utenfor bilen, viser at de ikke har tilstrekkelig erfaring, og trenger en påminnelse om risikoen ved dette. Det var også flere studenter som var mer opptatt av å få gjennomført sitt ferdig planlagte undervisningsopplegg og i mindre grad hadde en plan $\mathrm{B}$ og $\mathrm{C}$ i bakhånd, i den første observasjonsrunden. I runde to var studentene mye mer opptatt av elevenes behov og viste at de kunne håndtere disse. Dette viser at studentenes kommunikasjonskompetanse utviklet seg $\mathrm{i}$ riktig retning i løpet av studietiden, ved at de i større grad kunne gå utenfor manus etter hvert som erfaringen kom.

Refleksjon (teoretisk kompetanse) er viktig i studentens faglige og didaktiske utvikling. Mange av studentene viste utvikling av kyndighet når de etter å ha hatt en eller flere problematiske episoder i tidligere undervisning under andre observasjonsrunde underviste på et helt annet nivå. Jeg kan dermed anta at studenten både har søkt til teorien, reflektert og utprøvd ulike verktøy i praksis i mellomtiden. En av studentene sa under gruppeintervjuet: «Den personlige oppfølgingen vi får ute i praksis, er veldig nyttig. Da har vi mulighet til å reflektere sammen etter hver time, vi får tilbakemeldinger med en gang, og har muligheter til faglige innspill underveis.» Når dette gjennomføres i en gruppe med praksisveileder og medstudenter etter hver gjennomførte time, gir dette gode endringsmuligheter for studentene. En annen student sa: «Vi har forskjellige praksisveiledere og lærer ulike ting. Når vi ta det vi har lært og erfart med oss inn i klassefellesskapet på Kjeller, lærer vi også noe av de andres læring og erfaring fra sine praksisskoler.» En av praksisveilederne sa dette under intervjuet: «Det er refleksjonen under veiledningssamtalene som skaper endringene. Det er ikke om å 
gjøre å gjennomføre flest mulig timer i løpet av en dag som er det viktige, men arbeidet som legges ned før og etter timene.» Dette forteller om nytteverdien av refleksjonssamtalene ute i praksis, og refleksjonsrundene vi gjennomfører i felles klasse hver onsdag, etter at studentene har vært ute i praksis mandag og tirsdag.

Undervisningsferdigheter utvikles gradvis. Mange studenter viste tegn på kyndighet ved at de spesielt $\mathrm{i}$ andre observasjonsrunde skilte mellom når det var relevant å benytte veiledning, når instruksjon var mest relevant, og når både instruksjon og veiledning burde benyttes. Læreplanens vektlegging av problemorientert undervisning og krav om tilpasning til hver enkelt elev samt krav om utvikling av førerkompetanse i form av kunnskaper, ferdigheter, holdninger og motivasjon, viser at konfluent pedagogikk en relevant og hensiktsmessig tilnærming i undervisningen. Mange av studentene tilnærmet seg eleven med konfluent fokus, der det kognitive, motoriske og affektive var i fokus. Det er sannsynlig at elevene utvikler riktige holdninger til trafikkmiljøet, og handler ut fra en motivasjon om å bidra til et trafikksikkert miljø, når studentene legger vekt på det konfluente. Mange studenter viste at de behersket den konfluente tilnærmingen, og gjennom ulike veiledningsteknikker gjorde elevene i stand til å reflektere over egne handlingsmønstre, reaksjonsmønstre og begrensninger. Det viste seg blant annet gjennom refleksjonssamtalene som studentene gjennomførte med elevene i og etter undervisningen. Fra feltnotatene:

«Studenten benytter også skisser under samtalen om kjøring i vegkryss med vikeplikt. Han forklarer, og benytter i tillegg veiledende spørsmål der det passer: «Du setter ned farten i god tid. Hva er grunnen til det? Hva med myke trafikanter? Hva med sikten? Kan det være flere faktorer som bestemmer valg av fart?» Under kjøreturen stiller studenten gjennomgående spørsmål som: «Hvordan gikk det nå? Hva følte du når du nærmet deg krysset? Hva med fartstilpasningen? Vil du gjøre noe annerledes neste gang»? Her innleder studenten med instruksjon, men går raskt over til konfluent tilnærming ved bruk av veiledningsspørsmål.

Gjennom vår duale læringsmodell utvikler studentene en kjennskap til praksis som er viktig for utvikling av kyndighet. De vil etter hvert få kjennskap til og kunnskap om de mange ulike sidene ved å være trafikklærer, samt om hvordan en trafikkskole drives. Jeg har allerede fortalt at studenter i fjerde semester ordnet det meste på egen hånd. Her er et annet eksempel: Jeg kontaktet en av studentene ved en av praksisskolene med ønske om å få observere alle studentene ved denne skolen. Kort tid etter fikk jeg en mail av studenten. Da var alle avtaler på plass, og tidsskjemaet for mine planlagte observasjoner ble sendt til meg på mail. Noen av 
disse studentene hadde gjennomført opptil 250 praksistimer i andre studieår. De framsto som selvstendige og hadde god innsikt i alle sider ved trafikkskoledriften.

Den todelte kjernekategorien praksiskompetanse/kyndighet vokste etter hvert fram fra de fem hovedkategoriene. Praksiskompetanse og kyndighet hører sammen.

Praksiskompetanse består av mange faktorer. Sansing, ferdigheter og håndlag er helt nødvendige kompetanseelementer for å kunne utvikle seg som student og ikke minst vite hvordan lærestoffet skal tilrettelegges for hver enkelt kjøreelev. Mange studenter viste evne til å sanse trafikksituasjoner i god tid før de oppsto, samt å sanse hva eleven til enhver tid hadde behov for. Dette er kyndighetsformer som trafikklærerstudentene har utviklet på en god og riktig måte. Tekniske kjøreferdigheter som basis, og ferdigheter i å legge opp undervisning på en treffende og hensiktsmessig måte for den enkelte elev, viste de fleste studentene at de behersket da studiet nærmet seg slutten. Håndlag kan til en viss grad utvikles. Mange studenter viste et naturlig håndlag i både håndtering av bilen, av trafikksituasjoner og av tilrettelegging av lærestoffet. Andre har ikke den samme kompetansen, men nivået er likevel innenfor det som bør forventes. I intervjuet understreket praksisveilederne hvor viktig det er å ha håndlag, og var enig med studentene $\mathrm{i}$ at en dual læringsmodell er en forsterkende faktor for å utvikle dette. En av praksisveilederne gjenga dette etter å ha observert en samtale mellom student og kjøreelev før en kjøretime:

«Ja, hvordan har dagen din vært i dag, da Odd?» «Nei, den har ikke vært så veldig bra. Vi hadde prøve i matte, og nå er jeg helt tom.» Da svarer studenten: «Hva føler du at vi skal øve på i dag siden du ikke føler deg helt på topp?» «Vi kan repetere det jeg lærte sist time; jeg føler ikke at jeg orker å lære noe nytt i dag.» Her er studenten fokusert på noe helt annet enn «Sett deg inn i bilen og gjør deg klar!» Og da mener jeg at studenten har kommet langt.

\section{Drøfting}

I denne artikkelen har jeg ved å støtte meg på teori om blant annet kyndighet og praktisk klokskap (Inglar m.fl.) og en undersøkelse blant studenter og praksisveiledere, søkt å forstå og forklare hvordan vår duale læringsmodell bringer fram studentene til å bli godt forberedte trafikklærere. Resultatene i undersøkelsen har også synliggjort sårbarheten i vår læringsmodell. En sårbarhet som kan snus til styrke når en vet hva sårbarheten handler om. Hvordan vi kan tilnærme oss de sårbare elementene i læringsmodellen vil bli drøftet her.

I analysen av datamaterialet kom det som nevnt fram tre hovedtema som ble utledet av de fem hovedkategoriene og de to kjernekategoriene. 
Under det første hovedtemaet tyder resultatene på at planlegging er viktig; det er ikke alltid sammenheng mellom faglig sterke studenter og prestasjon i bil. Dette står i sammenheng med det Inglar skriver om kyndighet (Inglar, 2015, s. 20). Gjennom observasjonene ser det ut til at studentenes planlegging i mange tilfeller har større betydning enn kompetansenivået. Planlegging bidrar utvikling av kyndighet, og mangel på planlegging gjør det vanskelig å utvikle kyndighet hos studenten. Med dette menes at studenter som oppfattes som faglig sterke, og tilsynelatende har full kontroll på studiesituasjonen, faller igjennom i undervisningen av kjørelever dersom de ikke har en klar plan for timen før undervisningen tar til. Det så ut som om studentene ikke turte å gripe fatt i relevante trafikksituasjoner underveis i timen, sannsynligvis fordi det ville bli for mange elementer å gripe fatt i. I et trafikalt miljø som endrer seg hele tiden, kan resultatet av en manglende plan for time enten bli en kjøretur der lite faglig stoff blir tatt opp, eller en time der alt som tilfeldigvis dukker opp under kjøreturen blir tatt opp med eleven. Dette medfører i begge tilfeller dårlig læringsutbytte for eleven.

I motsatt fall, når studenten hadde arbeidet grundig med planlegging av timen, ble det ofte en stram struktur der studenten ikke lot seg friste til å ta opp alt som dukket opp av trafikale situasjoner, men holdt seg til temaet. Studenten stanset også ofte elever som stilte spørsmål om trafikale temaer som ikke hadde relevans til timens tema, med løfte om å komme tilbake til temaet senere.

Det ser derfor ut som det er fristende for faglig sterke studenter å slutte å legge planer for timene når de har studert en tid, fordi de føler seg for flinke. En student sa at han ikke lenger ville planlegge hver time fordi det tok så lang tid, og det ofte ble en kopi av planleggingen av tidligere timer. En annen student begrunnet manglende planlegging med at han følte at han hadde kontroll på timen uansett. Gjennom observasjonene så jeg imidlertid at planlegging er viktig for alle studenter, uansett om de er faglig sterke eller ikke.

Det tyder også på at det er en klar sammenheng mellom svake studenter og prestasjoner i bil. Faglig svake studenter hadde større utfordringer med undervisning av kjøreelever enn de øvrige studentene, både med tanke på kommunikasjon med eleven og med å klare å holde fokus på ett tema, sant å klare å tilpasse undervisningen til den enkelte elev.

En student viste tydelig frustrasjon overfor sin elev. Eleven gjorde en del feil som studenten mente kunne vært unngått dersom han hadde øvelseskjørt mer privat. Dette uttrykte studenten både direkte i ord og setninger, og med et kroppsspråk som tydelig viste 
frustrasjonen. Studenten og jeg samtalte om dette i etterkant av timen, og studenten var enig i at situasjonen ikke ble god og at læringsutbyttet for eleven ikke ble som forventet. I eksemplet over manglet studenten elementer av både teoretisk kompetanse om elever og læring, og praktisk kompetanse i å finne undervisningsformer som fremmer læring. Det vil imidlertid ikke være rettferdig å hevde at dette gjaldt generelt for denne studentens undervisning; dette var observasjoner gjort i en enkeltstående undervisningstime.

Det ser ut til at studentene blir flinke til å håndtere ulike elever når de er mye ute $\mathrm{i}$ praksis. Det betyr blant annet at de tilrettela undervisningen for ulike elevtyper på en god måte. De ble også flinke til å gjøre riktige didaktiske valg, eller med andre ord valg som passet til elevens behov. Trafikklærerstudentene må undervise mange forskjellige elever gjennom dagen, og venner seg dermed tidlig til å forholde seg til elever på ulikt nivå i trafikkopplæringen. En sideeffekt ved dette er at begrepsapparatet blir godt. I starten famler en del studenter i et hektisk trafikkmiljø når de må være ute i god tid med beskjeder til elevene. Men etter en stund har studentene ryddet $\mathrm{i}$ begrepene, og alt går mye bedre.

Under det andre hovedtemaet, som handler om begrepsforståelsen, tyder både observasjoner og intervjuer på at felles meningsinnhold i begrepene er en utfordring.

Vi bruker mye tid på alle samarbeidsmøtene med praksisveilederne til å drøfte ulike begreper som det er viktig å ha en felles forståelse av. Et eksempel på hvor viktig felles begrepsforståelse er, finner man under temaet «kommenterende egenkjøring»:

For å sikre at våre studenter får høyere kjøreferdighetsnivå og trafikal kompetanse enn kjøreelevene, gjennomfører vi to kjørevurderinger og en kjøretest i løpet av studiet, der studentene blant annet må snakke høyt og fortelle om hvilke planer de legger for videre kjøring ut fra en vurdering av trafikksituasjonene som oppstår («kommenterende egenkjøring»). Det er krevende å håndtere dette på en god måte, og samtidig ikke komme på etterskudd med selve kjøringen. Alle som har tatt trafikklærerutdanning i Norge har lært seg denne teknikken, men det er mange ulike oppfatninger av hva og hvor mye som skal kommenteres. Det føltes frustrerende for studentene at de lærte noe annet av sin praksisveileder enn det som var forventet under kjørevurderingene og under kjøretesten. Under et av samarbeidsmøtene mellom OsloMet og praksisveilederne ble innholdet og kravene i den kommenterende egenkjøringen drøftet, og vi ble enige om ett enkelt sett med kriterier som alle måtte følge. Det viser seg at det kan ta tid å endre noe som er godt forankret hos den enkelte, men vi er i hvert fall på vei mot en felles forståelse. 
Praksis er en bærebjelke i vår duale læringsmodell. En forutsetning for at studentene utvikler kyndighet og er godt forberedt på yrkeslivet er god relevans og sammenheng mellom teori og praksis.

Vi har hatt noen utfordringer med den faglige kontakten mellom universitet og praksisskole, ofte rundt felles forståelse av begreper. Praksisveilederne og faglærerne har for eksempel vært uenige om når veiledning kan benyttes, og når det er hensiktsmessig med mer instruksjonspreget undervisning. «Noe av bakgrunnen for manglende sammenheng mellom praksis og teori er at fagpedagogene og faglærerne har ansvaret for den teoretiske delen av lærerutdanningen, mens praksisveilederne som er ansatt i skolen har ansvar for praksis» (Hiim \& Hippe, 2011, s. 127), og «felles begrepsapparat letter kommunikasjonen» (Hiim \& Hippe, 2011, s. 134). Et viktig skritt på veien mot en felles begrepsforståelse og en felles plattform for utdanningen av trafikklærere, vil være å legge premissene for et nært og tett samarbeid mellom universitet og praksisskole. Det gjelder å bli enig om hvilke begreper som er de mest sentrale innenfor trafikkopplæringen og trafikksystemet, og deretter sørge for regelmessig drøfting av meningsinnholdet i begrepene.

«Mangel på sammenheng mellom fag-, pedagogikk- og praksisundervisningen er problematisk» (Hiim \& Hippe, 2011, s.12). Begrepet «konfluent pedagogikk» (Grendstad, 2014) har også vært utgangspunkt for diskusjoner mellom faglærere og praksisveiledere. Eleven skulle veiledes framfor å instrueres. Dette var nytt i trafikkopplæringen. Flere praksisveiledere har ment at man ikke kan veilede en elev i begynneropplæringen, og heller ikke være konfluent før eleven har et visst kunnskaps- og erfaringsnivå. De sier: «Når en elev skal sette i gang en bil for første gang, nytter det ikke å si til eleven: «Se om du kan finne noe som likner en gasspedal. Hva føler du når du trykker inn denne pedalen, og hva mener du at den kan brukes til?»» Et eksempel fra en av mine observasjoner antyder noe annet: Øvelsen «igangsetting i motbakke» skulle gjennomføres. Øvelsen foregikk på en vei med forholdsvis bratt stigning og med flere veier fra høyre der eleven fikk i oppgave å stanse før kryssene. Øvelsen forutsetter at eleven har $\varnothing v d$ mye på «krypekjøring», som er et samlebegrep for kjøring i så lav hastighet at clutchpedalen bestemmer farten, altså kjøring i meget lav fart. Krypekjøring bringes inn som en naturlig innledning til øvelsen: Studenten starter med å demonstrere bruk av pedalene for eleven, etter å ha spurt om hvordan eleven ønsker undervisningen lagt opp. Når dette er gjort, blir studenten og eleven enige om at studenten skal instruere de første igangsettingene for eleven. Eleven viser rask progresjon, og det går ikke lang tid før studenten kun gir korte beskjeder: «Stans» - «Sett i gang». Hver gang 
skolebilen har kommet til toppen av bakken, ber studenten eleven om å stanse inn til siden, hvorpå studenten spør: «Hvordan føler du at du mestret igangsettingene nå? Hva synes du gikk bra? Hvordan var det i forhold til sist gang? Hva mener du at du kan gjøre annerledes? Føler du deg trygg når du skal sette i gang? Hva vil du gjøre i neste runde?» Jeg registrerer at studenten har demonstrert, instruert og veiledet med konfluent fokus gjennom hele timen, selv om øvelsen foregikk på trinn 2 i trafikkopplæringen.

For å gjøre gapet mellom teori og praksis mindre, er det viktig at universitetet tar initiativ til møter med praksisskolene der slike eksempler bringes fram og drøftes, slik at oppfatningen av meningsinnholdet i begrepene blir så lik som mulig. Inglar sier at mangel på et yrkesrelevant begrepsapparat hemmer transformasjonen av erfaringer til refleksjon. «Det er gjennom yrkesopplæringen en lærer seg de relevante begrepene som kan gjøre narrativer overflødige» (Inglar, 2015, s. 29). Det trengs ofte ikke detaljerte beskrivelser av virkeligheten og mesterens livsverden dersom studenten selv får oppleve og erfare. Yrkesbegrepene står sentralt i studentenes og kjøreelevenes mulighet og evne til refleksjon, og er nært knyttet til studentenes erfaringer. Et relevant og felles begrepsapparat der meningsinnholdet oppfattes forholdsvis likt kan også bidra også til en effektiv og riktig undervisning av kjøreelever.

Et annet viktig skritt på veien mot en felles begrepsforståelse og en felles plattform for utdanningen av trafikklærere er tett oppfølging av studentenes praksis. I unders $\varnothing$ kelsen uttrykte både studenter og praksisveiledere at jeg skulle gi muntlig og skriftlig tilbakemelding i etterkant av observasjonene. Dette har foregått ved at vi har samlet oss i et rom på praksisskolen der vi har drøftet mine observasjoner. Jeg har i tillegg gitt råd og veiledning dersom det har vært ønske og behov for det. Faglærers nærvær og veiledning har også betydning for studentenes pedagogiske og didaktiske utvikling og prestasjoner. I tillegg har faglærers oppfølging betydning for praksisveilederne. Flere praksisveiledere uttrykte at de må skjerpe seg faglig når de har studenter i praksis og når faglærer kommer på praksisoppfølging. Dette kan også i noen tilfeller ha god innvirkning på praksisveileders oppfølging av studentene og etisk standard på driften av praksisskolen.

En tredje skritt på veien er å få på plass et godt etter- og videreutdanningstilbud for praksisveilederne og for studentene. Vi ser behovet for og nytten av at praksisveilederne, og studentene etter endt trafikklærerstudium, får tilbud om studier med relevant innhold. Fordypning i veiledning eller trafikkjus kan være eksempler på dette.

Dette er noen utsagn som er hentet fra fokusgruppeintervjuene. En student uttrykker seg slik: «Det å få tilbakemelding, det å trekke det rett tilbake til det vi driver med, det er særs 
viktig. Det burde kanskje vært mer av det. Der det er mulighet for det». En annen student sier: «Så de tilbakemeldingene som jeg har fått fra deg, har vært detaljerte og sagt mye om min undervisning, så jeg har lært mye». En praksisveileder sier: «Det er kjempeviktig at kommunikasjonen mellom universitetet og praksisskolene er så optimal som mulig, sånn at ikke studentene og vi føler at dere fraskriver dere ansvaret og sender opplæringsansvaret til oss». Faglærers oppfølgingsbesøk med veiledning, samt observasjoner med logg fra undervisningen, antas å ha stor betydning for både kommunikasjonen mellom universitet, praksisveileder og student, for behovet for et felles begrepsapparat, behovet for å gi studentene veiledning fra et annet synspunkt enn praksisveilederens, samt behovet for å vise praksisveiledere og praksisskole at universitetet tar ansvar for utdanning av studentene også når de er ute i praksis.

Det tredje hovedtemaet handler som nevnt om bransjekulturen. Undersøkelsen antyder at små enheter, tid og økonomi er modellens svake side. En antakelse har vært at studentene kan få en noe uensartet utdanning fordi de gjennomfører praksis hos små enheter av praksisskoler som har til dels ulik skolekode og ulikt syn på elementer i trafikkopplæringen. Undersøkelsen peker mot at dette har en viss sannhet. Det er mange små enheter i trafikkopplæringsbransjen, og det finnes faglig ledere, trafikklærere og praksisveiledere som arbeider hardt for å gi studentene best mulig læringsutbytte. Andre er mer opptatt av økonomi og at arbeid med studenter krever både tid og penger. Det gjør at enkelte studenter ikke føler seg tilstrekkelig ivaretatt. På den annen side tyder mine observasjoner, intervjuer og tilbakemeldinger fra studentene på at det er tilfredsstillende likhet mellom de praksisskolene og praksisveilederne som universitetet samarbeider med. Og praksisveiledere som til tider ikke har fulgt opp studentene godt nok, har vist vilje til å endre seg så fort de har blitt konfrontert med problemet.

Den største forskjellen mellom praksisskolene ligger altså mest på det økonomiske plan og i hvilken grad skolen klarer å skaffe elever til studentene. Her er det til tider stor variasjon, noe som igjen medfører ulikhet i hvilken oppfølging studentene opplever, og hvor mye de får mulighet til å undervise kjøreelever. Praksisskoler som sliter med elevtilstrømmingen har også praksisveiledere som ikke har mulighet til å følge opp studentene ofte nok fordi de må undervise selv for å få endene til å møtes. 


\section{Avslutning}

Resultatene i undersøkelsen indikerer samlet sett at studentene blir godt forberedt til yrkesutøvelsen gjennom vår duale læringsmodell, men under noen forutsetninger som kommer til syne gjennom modellens sårbarhet:

1. Studentene må sikes mye undervisningspraksis med konfluent tilnærming, og både praksisveiledere og faglærere må følge opp studentene grundig og ofte, slik at de føler seg ivaretatt og har mulighet til å utvikle sin kyndighet raskt og riktig

2. Studentene må forstå alvoret i utdanningen generelt og i praksis spesielt, og kan ikke velge bort grundig planlegging av undervisning fordi de mener at de har kontroll

3. Praksisveiledere og faglærere må fortsette å arbeide for felles forståelse av sentrale begreper, slik at studentene føler seg trygge på at alle har samme fokus og vil nå samme mål

4. Studentene må føle seg ivaretatt og ikke få følelsen av forskjellsbehandling bare fordi de har havnet på ulike praksisskoler

Det kan være naturlig å videreføre dette arbeidet med en undersøkelse av hvordan studenter som er utdannet ved OsloMet fungerer i trafikklæreryrket. Her bør både de tidligere studentene, de faglige lederne, kollegene ved trafikkskolen og kjøreelevene få uttale seg. Denne forskningen kan også rettes mot hvordan de tidligere studentene fra OsloMet fungerer i forhold til studenter fra Nord universitet og i forhold til studenter fra Sverige eller Danmark.

\section{Om forfatteren}

Anders Kristoffersen er universitetslektor ved OsloMet. Han har utdanning og erfaring som allmennlærer, som trafikklærer og som sensor i Statens vegvesen. Han har en mastergrad i yrkespedagogikk fra Høgskolen i Oslo og Akershus. Ved OsloMet arbeider han som faglærer og kullansvarlig ved trafikklærerutdanningen, og som ansvarlig for studiet Trafikkopplæring i skolen. 


\section{KILDER}

Boud, D. \& Solomon, N. (2001). Work-based Learning - A new higher education? SRHE (The Society for Research and Higher Education \& Open University Press)

Billett, S. (2008). Emerging perspectives on workplace learning. I S. Billett, A. Eteläpelto \&

Dalland, O. (2012). Metode og oppgaveskriving for studenter. Oslo: Gyldendal akademisk.

Dewey, J. (1916/1985). Democracy and education. An introduction to the philosophy of education. New York. Free Press

Dewey, J. (1938/2008). Erfaring og oppdragelse. Reitzel. København.

Eikeland, O. \& Hiim, H. (2015). Yrkespedagogiske perspektiver Gyldendal akademisk forlag

Haaland, G. (red) (2015). Tett på yrkesopplaring. Fagbokforlaget.

Hiim, H. \& Hippe, E. [1989] (2011). Praksisveiledning i laererutdanningen. Gyldendal Forlag.

Hiim, H. \& Hippe, E. (2009). Undervisningsplanlegging for yrkesfaglarere. Gyldendal Forlag.

Grendstad, N.M. (2014) [1986] Å lare er å oppdage. Didakta Norsk Forlag.

Grønmo, S. (2010). Samfunnsvitenskapelige metoder. Fagbokforlaget.

Inglar, T. (2009). Erfaringslaering og yrkesfaglarere. Høgskolen i Oslo og Akershus.

Inglar, T. (red) (2015). Erfaringslacring. Portal akademisk.

Johannessen, A., Tufte, P.A. \& Kristoffersen, L. (2004). Introduksjon til samfunnsvitenskapelig metode. Abstrakt Forlag.

Kvers $\varnothing \mathrm{y}$, K. (2015). Metodeeksperimenter med radikal medvirkning $i$ utdanning og forskning. HiOA.

Lovibond, S. (1995). Aristotelian etics and the «enlargement of thought». I R. Heinaman (red.) Aristotle and Moral Realism (s. 99-120). London: UCL Press.

NSD. Personverneombudet for forskning. Meld prosjekt. Hentet 15. juni 2015 fra http://www.nsd.uib.no/personvernombud/meld_prosjekt/index.html

Statens vegvesen. (2016). Håndbok V851. Laereplan for fфrerkortklasse B, B kode 96 og BE. Vegdirektoratet.

Torsmyr, K. (2007). Norsk trafikklaererutdanning i skjæeringspunktet mellom politikk, pedagogikk og trafikk i over 30 år. Høgskolen i Nord-Trøndelag.

Ulvik, M. Aksjonsforskning - en oversikt. I: Ulvik, M., Riese, H \& Roness, D. (2016) $\AA$ forske på egen praksis. Fagbokforlaget (s. 17-35) 